\title{
Trichoderma: Systematics, the Sexual State, and Ecology
}

\author{
Gary J. Samuels
}

U.S. Department of Agriculture-Agricultural Research Service, Systematic Botany and Mycology Lab., Rm. 304, B-011A, Beltsville, MD 20705. Accepted for publication 11 October 2005.

\begin{abstract}
Samuels, G. J. 2006. Trichoderma: Systematics, the sexual state, and ecology. Phytopathology 96:195-206.

A chronology is presented that charts the development of a genus and species concept in Trichoderma. Eighty-nine species of Trichoderma have been named, and several species of Hypocrea have been linked to unnamed Trichoderma anamorphs. Eighty-three taxa of Trichoderma and their teleomorphs, Hypocrea spp., have been included in phylogenetic analyses, including 11 species of Hypocrea with unnamed Trichoderma anamorphs. Phylogenetic analyses show that Trichoderma and Hypocrea are congeneric. Trichoderma species not linked to Hypocrea teleomorphs are derived from among species that are linked to teleomorphs, indicating sexual and asexual lineages are not independent of each other. Many more species remain to be discovered and described. Molecular phylogenetic analyses have revealed the existence of more species than have been recognized on the basis of morphology alone. A suggestion is made to modify the International Code of Botanical Nomenclature to enable
\end{abstract}

ABSTRACT adoption of a single generic name for TrichodermalHypocrea, with Trichoderma being the older and more utilitarian name. As increasing numbers of species are studied, the few morphological characters of anamorph and teleomorph have reached their limit for defining species. DNA-based characters have assumed an indispensable role. Exploration of new niches, such as within tree trunks and new geographic locations, have resulted in a substantial increase in the number of species of Trichoderma. Trichoderma is usually considered a genus of free-living soil fungi but evidence suggests that Trichoderma species may be opportunistic, avirulent plant symbionts as well as parasites of other fungi. Members of the genus Trichoderma are universally present in soils, although individual species may be either cosmopolitan (e.g., T. harzianum) or limited (e.g., T. viride) in their geographic distribution. To facilitate identification of species, a list of correctly identified strains of Trichoderma and their GenBank numbers for sequences of translation-elongation factor EF- $1 \alpha$ and internal transcribed spacer rDNA is provided.
The Trichoderma chronology. Identification of Trichoderma species is notoriously difficult. The few morphological characters available are variable to some degree, leading to overlap among species; this could explain why so few species have been described over most of the life of the genus. An unfortunate result of the failure of taxonomists, until recently, to provide the basics for species identification is that strains reported in the literature may have been misidentified. Kullnig et al. (63) reidentified several strains as Trichoderma harzianum that had been reported in the literature under different names. How have we come to this state of species recognition, and what are we doing to improve the situation? To understand this, it is essential to review how the taxonomy of Trichoderma has developed. The appreciation of what constitutes a species of Trichoderma, or even of what constitutes the genus, has been incremental and free of a plethora of names that cannot be pinned down, or competing taxonomic systems, both of which have plagued taxonomy of other economically important genera such as Fusarium. Following is a summary of the highlights in this development.

Trichoderma was first proposed as a genus by Persoon in 1794 (77) on the basis of material collected in Germany. Persoon included four species and evidently had difficulty recognizing his own genus because, of the four species originally included in the genus, only one-T. viride - remains in Trichoderma. In 1865, the Tulasne brothers (99), in France, elegantly illustrated a link be-

Corresponding author: G. J. Samuels; E-mail address: gary@ nt.ars-grin.gov

DOI: 10.1094/PHYTO-96-0195

This article is in the public domain and not copyrightable. It may be freely reprinted with customary crediting of the source. The American Phytopathological Society, 2006 tween T. viride and a sexual stage, Hypocrea rufa. Their illustrations are the standard of identification for this holomorph. Prior to 1969, few species were added to Trichoderma. Over time a few genera, each including one or a few species, were synonymized with Trichoderma thereby expanding the concept of the genus to include species that produced hairs and colorless (white in mass) conidia as well as characteristic species with green conidia. With this expansion in generic concept one might think that the flood gates for description of new species would have been opened, but that was not the case. In 1927, Abbott (1) only recognized four well-defined groups among the intergrading Trichoderma isolates from soil but distinguished only three species in a key; two of them are now considered to be synonyms of T. viride. In 1939, Bisby (8) expressed what probably most people feel even today: they all look the same! He was not able to distinguish between $H$. rufa, a species with colorless ascospores, and $H$. gelatinosa, a species with green ascospores. One would not think it difficult to distinguish between these two species because of the difference in ascospore colors, and the anamorph of $H$. gelatinosa, T. gelatinosum, is easily distinguished from that of true H. rufa, T. viride. For whatever reason, Bisby could not see the differences and the practical result was a taxonomy that reduced most of Trichoderma to a single species, T. viride. This system was in place until 1969. Needless to say, this single-species system was very popular; certainly no special skills were required to reach an identification, and only few species were added until 1969. In 1957, Dingley (31), characterizing the Trichoderma anamorphs of several species of Hypocrea in New Zealand, identified all of the anamorphs as typical of $T$. viride.

Bisby's one-species system prompted John Webster and student Mein Rifai to review taxonomy of Trichoderma and Hypocrea by examining life cycles of identified Hypocrea species $(81,82,102$, 
103). They took the approach that the addition of characters from a teleomorph would help to define Trichoderma. Their work culminated in the 1969 publication of Rifai's thesis (80), a groundbreaking monograph of Trichoderma. In this work he recognized nine aggregate species, some of which were isolated from Hypocrea specimens. He emphasized that his was not the last word but was rather a preliminary attempt to establish a natural and workable system based on patterns of variation in Trichoderma isolates, especially those derived from Hypocrea specimens of unquestionable identity. Further, he acknowledged that each of the "aggregate" species could comprise two or more cryptic species-a small but important detail that was largely overlooked as Rifai's work quickly became, and then remained, the unchallenged authority for Trichoderma for 15 years. Significantly, Rifai excluded Gliocladium virens from Trichoderma while noting that it was not $T$. viride; G. virens, now $T$. virens, was the name used in the first publications describing the fungistatic compounds gliotoxin and viridin in the mid-1940s (15-17).

Between 1972 and 1989, Doi monographed Hypocrea for Japan and published several papers describing the life cycles of tropical species of Hypocrea. He (36) proposed subdivisions of Hypocrea based on anatomy of the stroma and on the anamorph. This work remains the only overall study of Hypocrea and its closest relatives for a geographic region, although individual species and groups of species have been monographed recently $(21,22,24-27$, $32,33,68-71,89)$.

Between 1984 and 1992, Bissett (9-13) undertook a revision of Trichoderma using Rifai's work as the foundation. Essentially, Bissett viewed some of Rifai's aggregate species to be sections and, within those sections, Bissett recognized biological species. In place of nine aggregate species, Bissett (10) formally recognized four sections, of which he monographed two. Bissett rarely considered teleomorphs in his work.

In about 1995, the use of DNA sequence analysis became the new paradigm in fungal systematics and Trichoderma workers quickly incorporated sequence data to the developing taxonomy of Trichoderma and Hypocrea. The early work is reviewed by Lieckfeldt et al. (66). Most significant among the early publications is the demonstration that the genus Gliocladium is paraphyletic, comprising at least three phylogenetically and morphologically distinct groups, and that $G$. virens is a species of Trichoderma not Gliocladium (78), confirming the largely ignored new combination proposed by von Arx in 1987 (5). In 1995, Rehner and Samuels (79) demonstrated the derivation of apparently asexual fungi from within clades that include sexual fungi and that Trichoderma is phylogenetically indistinguishable from Hypocrea. Christian Kubicek and his group explored the generic phylogeny of Trichoderma using, first the internal transcribed spacer (ITS) region of rDNA (55), and later used multiple genes (64).

Trichoderma: A definition of a genus and its species and a discussion of sex. Prior to the mid-1990s the course of evolution in fungi-phylogeny-was plotted from phenotype, cytology, physiology, ultrastructure and to a small extent fossils and so on. Cladistic analysis of phenotype data provided a powerful tool for reconstructing phylogenies in character-rich groups such as arthropods, but was slow to be adopted by mycologists because of the paucity of characters (104). DNA sequencing, which became routine in the mid-1990s, provided the great number of characters, in the form of diverging base pairs, which invite cladistic analysis. Regarding microfungi, traditional phylogenetic schemes were supported mainly by the new, independently derived sequence data (90). Before long the analysis of DNA characters came to be synonymous with phylogenetic analysis. Today, sequences of multiple genes are used to infer phylogenies of taxa at all levels and also to infer the evolution of physical traits (72). The reigning species concept, which relies on the comparison of more than one gene genealogy, is known as Genealogical Concordance Phylogenetic Species Recognition (GCPSR; 97).
The fundamental questions-what is Trichoderma? what are its relatives? what are its limits? how many species?-could not be answered satisfactorily with classical methods. Thanks to DNA sequencing, these questions can be answered. Of course, the link between Trichoderma and Hypocrea was known since at least the mid-19th century (99), but Rehner and Samuels (79) and subsequent authors $(22,64)$ revealed that even Trichoderma species, and members of other genera not known to be linked to teleomorphs, are not distinguishable from their sexually reproducing counter parts. With additional fieldwork, a growing number of named Trichoderma species have been linked to Hypocrea teleomorphs, such as $T$. harzianum, the anamorph of $H$. lixii (24), or T. virens, the anamorph of $H$. virens (26). However, some common and important species such as $T$. asperellum have not been linked to a teleomorph and are apparently clonal.

A phylogenetic concept has been developed that is highly consistent with the "typical" Trichoderma phenotype. Most Trichoderma do not look very different from the stereotype of the genus: lots of powdery green conidia in fast-growing colonies. However, not all species that fall within the phylogenetic concept of the genus are morphologically typical. T. virens was included in Gliocladium because of its gliocladium-like aspect: phialides held in a penicillus, conidia held in drops of clear green, watery liquid. No true species of Gliocladium can be included in Trichoderma so $G$. virens is $T$. virens $(5,78)$. True Gliocladium is a genus of fungi that occurs on bracket fungi and that has teleomorphs in Sphaerostilbella (92). One phylogenetic lineage within Trichoderma is characterized by the production of white conidia from conidiophores typical of the genus Pachybasium Sacc. T. hamatum (Link:Fr.) Rifai, the type species of Pachybasium is also derived from within Trichoderma (71). Several Hypocrea species have anamorphs that are anything but typical of Trichoderma, being acremonium- or verticillium-like with colorless conidia. $H$. citrina and its relatives, a phenotypically and phylogenetically homogeneous assemblage of species (75), are derived from within Trichoderma but their anamorphs are acremonium- and verticilliumlike; this group includes T. lactea and other members of Trichoderma sect. Hypocreanum. The possibility exists that these Hypocrea species have lost the typical Trichoderma morph but have retained a spermatial morph. In at least one species of Hypocrea, both typical Trichoderma and acremonium-like morphs form (87). H. avellanea, a parasite of the mushroom Collybia subnuda in forests of eastern North America, produces a verticillium-like anamorph (20). H. flavovirens has a Stilbella anamorph (93). The common soil fungus $G$. viride (with the better known name G. deliquescens as a later synonym) is the anamorph of H. lutea, which is an undoubted species of Hypocrea (25). Although the anamorph of this species would not be confused with a true Gliocladium, it is very un-trichoderma-like, and despite its phylogenetic unity with Trichoderma, it has never been placed nomenclaturally in the genus. Similarly, the anamorphs of $H$. cinereoflava (Stilbella flavipes [93] and H. pallida [Gliocladium]) are completely inconsistent with any morphological concept of Trichoderma. Phylogenetic analysis shows that $H$. pallida is, in fact, not a species of Hypocrea and requires a new genus (78). $\mathrm{H}$. cineroflava has not been included in any phylogenetic analysis, but the divergent phenotype of its anamorph suggests that it also should be excluded from Hypocrea.

Trichoderma is typically thought of as producing only one form of asexual spores, viz. green conidia from a single kind of conidiophore. We now know that some species produce chlamydospores $(11,26)$, which are very abundant and conspicuous in $T$. virens. Chaverri et al. (22) described synanamorphs for several species of Trichoderma that produce their conidia from pustules. These synanamorphs form their conidia on verticillium-like or gliocladiumlike conidiophores in aerial mycelium; these are morphologically quite different from the typical Trichoderma conidiophores that form in the same cultures. The conidia are held in drops of clear, 
green liquid. When the synanamorph is formed in abundance, one could even think that the culture had become contaminated. As above, a spermatial (?vestigial) function for the synanamorphs is suggested (87).

There are few examples of Trichoderma/Hypocrea species undergoing sexual reproduction in vitro and, in my experience, this is a rare thing. One very well-known example, however, is of what is known in the literature as Chromocrea spinulosa $(=H$. spinulosa). In this species, half of the ascospore progeny were self sterile and the other half were self fertile but when the selfsterile spore progeny were paired with the self-fertile progeny, perithecia formed along a strong line contact, indicating that the two sterility types were of opposite mating types as well (73). This was explained by a mutation of nuclei in the mycelial hyphae of the self-fertile strains to the mating type of the selfsterile strains, leading to the self fertility; this phenomenon is known as mating-type switching and has been observed to occur in other unrelated fungi (76). H. citrina var. citrina and $H$. citrina var. americana readily produce perithecia in culture and appear to have the same type of mating system as is seen in $H$. spinulosa (18), but the mating system in these two taxa has not been studied in detail. Similarly, $H$. poronioidea produces self-fertile and self-sterile spore progeny in the ascus but perithecia did not form when self-fertile and self-sterile progeny were mated, moreover hyaline-possibly spermatial-conidia formed in close association with developing perithecia (87). The tropical species $H$. jecorina, the teleomorph of $T$. reesei, manifests a typical bipolar heterothallism with the two mating types segregating in the ascus in a $4: 4$ ratio (67); it is the only species known to behave this way.

Molecular phylogenetic methods have been used to test competing hypotheses about the number of species in Trichoderma and it is now clear that there are more rather than fewer. To date, 83 taxa (species, forms, and varieties) of Trichoderma and Hypocrea have been included in phylogenetic analyses. These include 72 named species of Trichoderma, 19 of which have not been linked to Hypocrea teleomorphs (Table 1). A summary phylogram is shown in Figure 1. Important anamorph/teleomorph links include $T$. reesei/H. jecorina (62), which is a primary source of cellulase enzymes, and three biological control species: T. virens/ H. virens (26), T. harzianum/H. lixii (24), and T. stromaticum/ H. stromatica (7). It should be noted that about 400 species of Hypocrea have been described in the past 200 years and only very few of them have been grown in pure culture. Doi (34-39) linked many species of Hypocrea to unnamed Trichoderma anamorphs, but his original cultures are no longer viable.

At this time a single gene is not considered sufficient to characterize species of Trichoderma and Hypocrea and new species are resolved using multiple genes, including actin, calmodulin, endochitinase, and translation-elongation factor $(14,22,71)$. Each of the 83 species is represented in GenBank by sequences of at least the ITS region of rDNA, and most are represented by sequences of the protein-coding gene translation-elongation factor 1- $\alpha$ (tef). Although generally the ITS region is species specific, identifications based on ITS sequences must be used with caution because sometimes closely related species cannot be distinguished using this gene. This is especially true of Trichoderma sect. Trichoderma, which includes $T$. viride, where more than one species can share the same ITS sequence (70; G. J. Samuels, unpublished data). Because tef is more variable than the ITS rDNA, it is better able to reflect species differences within and among groups of closely related species. Unfortunately, at least three different primers have been used in tef studies in Trichoderma, making it impossible to identify unknowns by BLAST searching using a single primer (contrast 22,64,85). In our laboratory, we use the primers ef1-728 (19) and tef1 rev (85), which results in a polymerase chain reaction product of approximately $600 \mathrm{bp}$, which is sequenced in both directions.
A further problem with identifying isolates by BLAST searching GenBank is the number of sequences deposited for misidentified strains. Table 1 lists correctly identified strains and their corresponding GenBank numbers for tef and ITS sequences. An interactive key to identification of several Trichoderma species based on ITS and multiple genes, including a short part of tef, can be found online by the International Subcommission on Trichoderma and Hypocrea (ISTH) $(41,42)$. Traditional keys to the most common species are available in Gams and Bissett (44), and most species are illustrated in an interactive key provided online by the Systematic Botany \& Mycology Laboratory, USDAARS (84).

The molecular studies essentially support the morphologically based taxonomy proposed by Bissett (9-13), although the arrangement of species in morphologically defined sections is not supported and individual species may be too broadly conceived. Two of the sections that he proposed, sects. Longibrachiatum, which includes T. reesei, and Hypocreanum, are phylogenetically and morphologically homogeneous. Sect. Saturnisporum has been amalgamated with sect. Longibrachiatum $(61,89)$. Sect. Pachybasium, which includes $T$. hamatum, $T$. harzianum, and $T$. virens along with most other species in the genus, is paraphyletic (25, $55,64)$, and many of the species in sect. Pachybasium now join $T$. viride and T. koningii in sect. Trichoderma. As more species are included in phylogenetic analyses, the sectional definitions lose their meaning and, although closely related species are typically morphologically similar, species in the same clade may have quite different morphology. Moreover, as additional species are studied, new clades are discovered (53). Currently, there is no acceptable formal subdivision of Trichoderma or Hypocrea, and as new species are added, the genus appears to become more complex. Today, only sect. Longibrachiatum (including sect. Saturnisporum) is monophyletic. Jaklitsch et al. (53) have essentially dropped reference to sections and instead have adopted a reasonable approach of giving informal names to clades and lineages.

Commonly reported species have been evaluated using molecular phylogenetic techniques. DNA sequence analysis has revealed the existence of morphological species, that is, morphologically cryptic species within phylogenetic species. Rifai (80) recognized that what he referred to as a species was often an amalgam of two or more biological species. The truth of this statement is revealed in the DNA sequence analyses. For example, the widely reported $T$. viride was known to be the only species to have warted, subglobose conidia, but now we know that at least three species share this conidial character $(70,86)$; searching for characters beyond the conidia has revealed differences in the conidiophore that have been overlooked previously. T. koningii represents a conserved morphology in Trichoderma sect. Trichoderma. Phylogenetic analysis reveals that true $T$. koningii is limited in distribution. From this complex, so far two species have been described (T. ovalisporum and $H$. stilbohypoxyli [50]); both share the $T$. koningii morphology but differ from that species in subtle morphological characters and in characters of colonies. At least nine more species that would have been identified as $T$. koningii are known to form monophyletic lineages and remain to be described (G. J. Samuels, unpublished data). Each of these lineages shows a strong geographic bias. On the other hand, Grondona et al. (46) and Hermosa et al. (49) questioned whether T. harzianum represents more than one species. In response, Chaverri et al. (23) studied a wide morphological and geographic diversity of isolates using four genes. They concluded that this common, cosmopolitan species is a species complex with distinct, partly geographically defined phylogenetic lineages that lacked diagnostic morphological characters.

The subdivisions of Hypocrea, the teleomorph, based on the anatomy of the stroma proposed by Doi (36), have not held up either, although there is a tendency for closely related species to share sexual state to such an extent that the species can only be 
TABLE 1. Correctly identified Trichoderma/Hypocrea species and their translation/elongation factor 1- $\alpha$ (EF-1 $\alpha$ ) and internal transcribed spacer (ITS) rDNA GenBank numbers ${ }^{\mathrm{a}}$

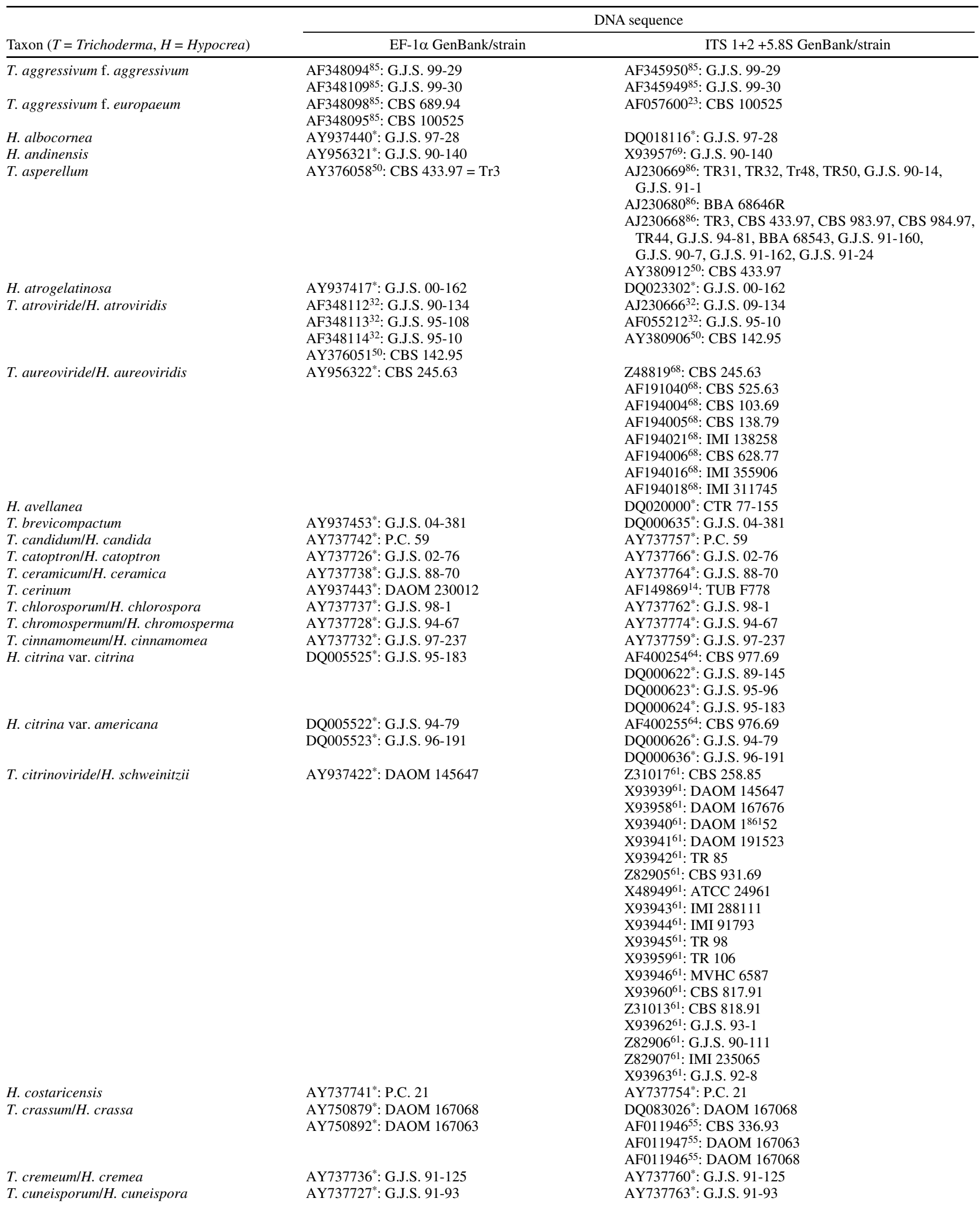

\footnotetext{
a Superscript numbers refer to publications in which the GenBank number is cited. * Indicates new sequences deposited here using the primers $e f 1-728$ (19) and
} tef1 $\mathrm{rev}\left({ }^{85}\right)$, which results in a polymerase chain reaction product of approximately $600 \mathrm{bp}$, which is sequenced in both directions. 
TABLE 1. (Continued from preceding page)

\begin{tabular}{|c|c|c|}
\hline \multirow[b]{2}{*}{ Taxon $(T=$ Trichoderma,$H=$ Hypocrea $)$} & \multicolumn{2}{|c|}{ DNA sequence } \\
\hline & EF-1 $\alpha$ GenBank/strain & ITS $1+2+5.8 \mathrm{~S}$ GenBank/strain \\
\hline T. effusum & AY937419*: DAOM 230007 & AF149858 ${ }^{14}:$ DAOM 230007 \\
\hline T. erinaceus & AY750879*: DAOM 230019 & DQ083009*: DAOM 230019 \\
\hline T. estonicum/H. estonica & AY737733*: G.J.S. 96-129 & AY737767*: G.J.S. 96-129 \\
\hline T. fasciculatum & AY750895*: DAOM 167646 & DQ087258*: DAOM 167646 \\
\hline \multirow[t]{3}{*}{ T. fertile } & AY750881*: DAOM 167161 & DQ083018*: DAOM 167161 \\
\hline & & AF011952 $55:$ DAOM 167070 \\
\hline & & AF012002 $55:$ DAOM 195118 \\
\hline H. flaviconidia & DQ020001*: G.J.S. 99-49 & DQ023301*: G.J.S. 99-49 \\
\hline T. gelatinosus/H. gelatinosa & AY737740*: G.J.S. 88-17 & AY737775*: G.J.S. 88-17 \\
\hline \multirow[t]{6}{*}{ T. ghanense including T. parceramosum } & AY937423*: G.J.S. 95-137 & Z6958861: TNS-F 237181 \\
\hline & AY937420*: G.J.S. 99-38 & $\mathrm{Z} 31015^{61}:$ ATCC $28019=\mathrm{CBS} 259.85$ \\
\hline & & Z4893661: DAOM 165776 \\
\hline & & X9396161: DAOM 190843 \\
\hline & & X93947 ${ }^{61}:$ CBS 135.79 \\
\hline & & Z48727 $61:$ NRRL 3091 \\
\hline \multirow[t]{2}{*}{ T. hamatum } & AY750893*: DAOM 167057 & DQ083017*: G.J.S. 99-198 \\
\hline & DQ151582*: T-382 = G.J.S. 04-368 & DQ151583*: T-382 = G.J.S. 04-368 \\
\hline \multirow{26}{*}{$\begin{array}{l}\text { T. harzianum/H. lixii } \\
\text { including } T \text {. inhamatum }\end{array}$} & AY737729*: G.J.S. 90-22 & AY737761*: G.J.S. 90-22 \\
\hline & AF348100 85 : CBS 227.95 & $\mathrm{Z} 68187^{69}:$ CBS 273.78 \\
\hline & AF348101 ${ }^{85}$ : CBS 226.95 & AJ22272085: CBS 226.95 \\
\hline & AF34809985: CBS 273.78 & AF345948 ${ }^{85}$ : G.J.S. 95-81 \\
\hline & AF34810285: G.J.S. 95-81 & AF19401085: G.J.S. 97-263 \\
\hline & AF348091 ${ }^{85}$ : G.J.S. 97-263 & AF194011 ${ }^{85}$ : G.J.S.97-264 \\
\hline & AF34810385: G.J.S. 97-264 & AF194013 85 : G.J.S. 97-266 \\
\hline & AF34809085: G.J.S. 97-266 & AF194015 85 : G.J.S. 97-268 \\
\hline & AF348105 85 : G.J.S. 97-268 & AY027780 85 : G.J.S. 99-230 \\
\hline & AF34809285: IMI 359823 & AY02778385: G.J.S. 99-231 \\
\hline & AF34810785: G.J.S. 99-230 & AY027784 ${ }^{85}$ : G.J.S. $99-227$ \\
\hline & AF34810885: G.J.S. 99-231 & AY027781 85 : G.J.S. 97-265, G.J.S. 99-225 \\
\hline & AF348093 85 : G.J.S. 99-227 & Z6818785: CBS 273.78 \\
\hline & AF348104 ${ }^{85}$ : G.J.S. $97-265$ & AF27533023: G.J.S. 98-183 \\
\hline & & AF44391923: G.J.S. 92-100 \\
\hline & & AF443916 23 : G.J.S. 94-53 \\
\hline & & AF443925²3: G.J.S. 92-61 \\
\hline & & AF194012 ${ }^{85}$ : G.J.S. 97-265 \\
\hline & & AF44391423: G.J.S. 00-06 \\
\hline & & AF44391423: G.J.S. 00-08 \\
\hline & & AF44391323: G.J.S. 00-18 \\
\hline & & AF44392823: G.J.S. 00-21 \\
\hline & & AF44391223: G.J.S. 00-22 \\
\hline & & AF443922 23 : G.J.S. 00-24 \\
\hline & & AF469188 23 : Harman 129522 \\
\hline & & AF443911 $23:$ DAOM 222136 \\
\hline \multirow[t]{5}{*}{ T. helicum } & AY937416*: DAOM 230016 & DQ083022*: DAOM 230016 \\
\hline & AY937433*: DAOM 230017 & AF486021"14: TUB F293 \\
\hline & & AF486021 $14:$ TUB F 922 \\
\hline & & AF48602014: TUB F902 \\
\hline & & AF48602014: TUB F903 \\
\hline \multirow[t]{2}{*}{ T. konilangbra } & AY937425*: G.J.S. 96-147 & DQ083021*: G.J.S. 96-147 \\
\hline & & AF400261 ${ }^{64}:$ G.J.S. 96-146 \\
\hline \multirow[t]{4}{*}{ T. koningii/H. koningii } & AY376045 50 : G.J.S. 89-122 & Z79628 $69:$ ATCC 64262, CBS 457.96, CBS 458.96, \\
\hline & & CBS 459.96, CBS 460.96, CBS 979.70, CBS 988.97, \\
\hline & & CBS 987.97, CBS 989.97 \\
\hline & & AY380902 0 : G.J.S. $89-122$ \\
\hline H. lacuwombatensis & AY937452*: G.J.S. 99-198 & DQ083017*: G.J.S. 99-198 \\
\hline T. longibrachiatum & AY937412*: ATCC $18648=$ TR $97=$ CBS 816.68 & $\mathrm{Z} 31019^{69}:$ ATCC 18648 \\
\hline T. longipile & AY937430*:DAOM 177227 & AF01197571, AF39849371: DAOM 177227 \\
\hline Gliocladium viride/H. lutea & AY737731*: G.J.S. 89-129 & AY737773*: G.J.S. 89-129 \\
\hline T. melanomagnum/H. melanomagna & AY737751*: G.J.S. 99-153 & AY737770*: G.J.S. 99-153 \\
\hline T. minutisporum/H. minutispora & AY750883*: DAOM 167069 & DQ083015*: DAOM 167069 \\
\hline \multirow[t]{3}{*}{ H. neorufa } & AF487670 33 : G.J.S. $96-135$ & AF48765333: G.J.S. 96-132 \\
\hline & AF487672 33 : G.J.S. 96-143 & AF487654"33: G.J.S. 96-143 \\
\hline & AF487671 ${ }^{33}$ : G.J.S. 87-72 & \\
\hline T. nigrovirens/H. nigrovirens & AY737744*: G.J.S. 99-64 & AY737777*: G.J.S. 99-64 \\
\hline H. novaezelandiae & AY937448*: G.J.S. 81-265 & DQ083019*: G.J.S. 81-265 \\
\hline & & X9396961: CBS 496.97 \\
\hline & & X9396761: ICMP 1694 \\
\hline & & X93968 $61:$ CBS 472.97 \\
\hline T. oblongisporum & AY750884*: DAOM 167085 & DQ083020*: DAOM 167085 \\
\hline H. orientalis & AY $937421^{*}:$ CBS 243.63 & X9396461,89: G.J.S. 88-81 \\
\hline & & X93966 ${ }^{61,89}:$ ICMP 5426 \\
\hline & & Z4893561,89: ATCC 52326 \\
\hline & & (Continued on following \\
\hline
\end{tabular}


TABLE 1. (Continued from preceding page)

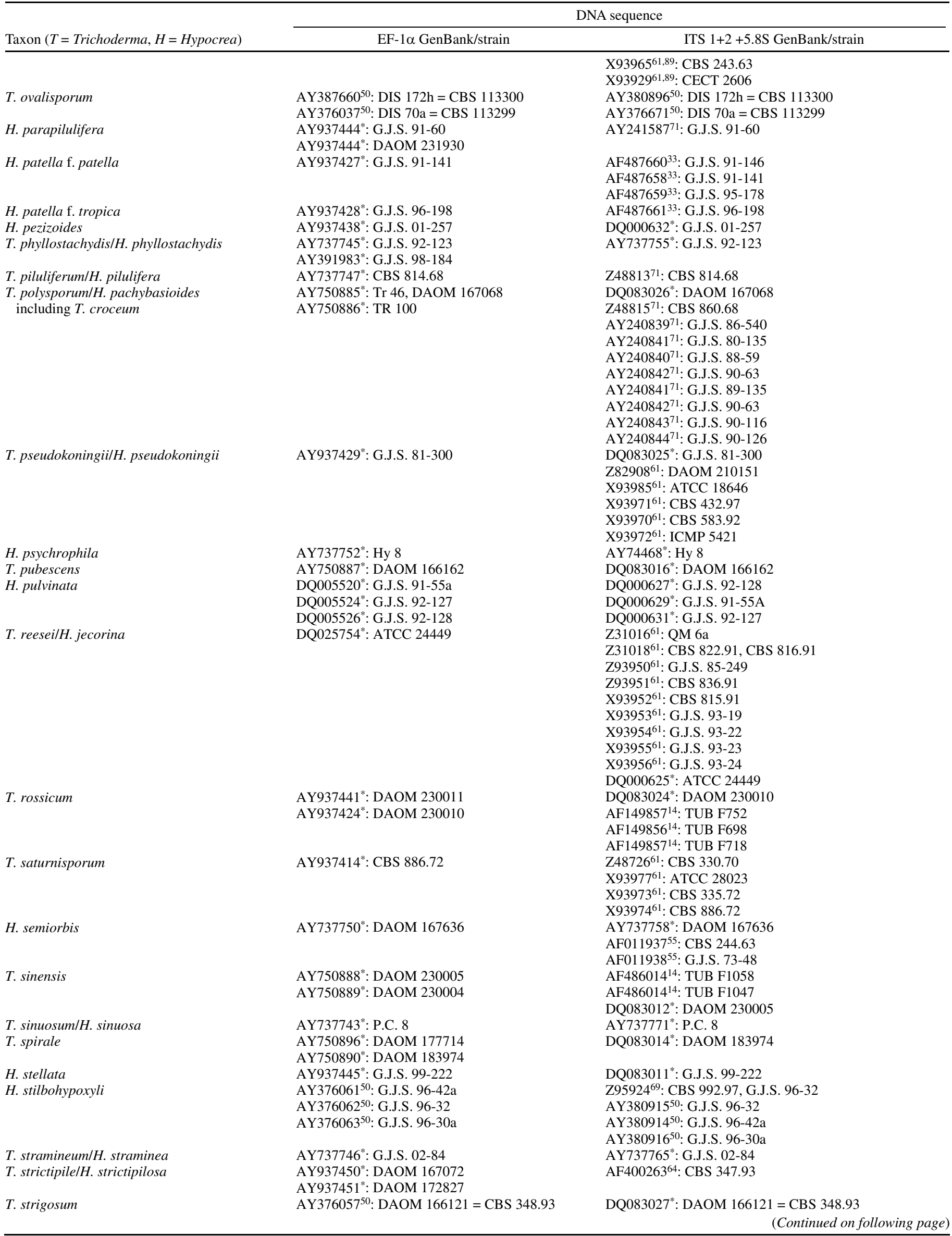


distinguished on the basis of the phenotype of cultures or of the anamorph.

The phylogenetic tree for Trichoderma is growing. The tree shown in Figure 1, which is modified from Chaverri and Samuels (25), shows representative species. With some modification, the names of the clades follow Jaklitsch et al. (53). With this tree, one is able to see the distribution of biological properties. For example, the most common, medically important Trichoderma species are found in sect. Longibrachiatum; it is in this section where species produce cellulase in high titre (59) and only in this section are species found that can grow and sporulate at $40^{\circ} \mathrm{C}$. Many biological control species are found in the harzianum-virens and viride clades, and although the production of the antifungal antibiotic 6pentyl- $\alpha$-pyrone may be widespread in Trichoderma $(30,45,54)$, the characteristic coconut odor may be produced only by members of the viride clade, most notably $T$. atroviride. Trichothecene mycotoxins, which may be involved in mycotoxicoses of farm animals, are reportedly produced by a number of Trichoderma species (94); however, it is difficult to evaluate the reports in taxonomic terms because some of the names are of uncertain application (e.g., T. sporulosum and T. lignorum). T. harzianum ATCC 90237, reported to produce T2 toxin harzianum A (94), is $T$. brevicompactum and unrelated to $T$. harzianum. According to Nielsen et al. (74), the strain originally described as producing trichodermin is also T. brevicompactum. In a limited survey of Trichoderma species, they found trichothecene production only in $T$. brevicompactum, whose closest relative is $H$. lutea/G. viride (Fig. 1). Their study suffers from not having investigated $T$. polysporum, strains of which are reported to produce both trichodermin and trichodermol.

Geographic distribution of Trichoderma species. Although the genus Trichoderma is represented in soils and other organic matter collected at all latitudes, some species are widely distributed while other species are geographically limited in their distribution. Based on my own observations, T. polysporum and T. minutisporum are species of cooler lands. The name $T$. viride, as mentioned above, refers to a morphological species; true $T$. viride is a rather uncommon species of cooler northern regions. The same can be said for the widely reported $T$. aureoviride, which seems to be limited to the United Kingdom and northern Europe (68). The numerous reports of $T$. pseudokoningii in the literature imply a wide distribution for the species but Turner et al. (100) found it to be an Australasian species. T. reesei, the species best known for the commercial production of cellulase enzymes, was until recently known only from a single culture isolated from canvas material in the Solomon Islands of the Pacific region. We now know that this is the anamorph of $H$. jecorina (62), a species that is limited in its distribution to a narrow Equatorial band, and we have isolated it directly from natural substrata in Brazil and French Guiana (67). T. stromaticum (88) has perhaps the most restricted distribution of any species in the genus; it is found only in tropical America and then in association with cacao (Theobroma cacao) trees or with the pathogen that causes witches' broom of cacao, Crinipellis perniciosa (=Moniliophthora; 2). T. stromaticum is effective in control of this disease (91). Turner et al. (100) observed that T. longibrachiatum was found in North and South America, Europe, Africa, and India but not in Southeast Asia or Australasia, while the closely related T. citrinoviride is found in North and South America, Europe, Southeast Asia, and Australasia but not in Africa and India. Some species of Trichoderma such as T. harzianum (23) and T. asperellum (G. J. Samuels, personal observation) are truly cosmopolitan.

Trichoderma in the environment. The ecology of Trichoderma was reviewed in Klein and Eveleigh (56). Trichoderma

TABLE 1. (Continued from preceding page)

\begin{tabular}{|c|c|c|}
\hline \multirow[b]{2}{*}{ Taxon $(T=$ Trichoderma, $H=$ Hypocrea $)$} & \multicolumn{2}{|c|}{ DNA sequence } \\
\hline & EF-1 $\alpha$ GenBank/strain & ITS $1+2+5.8 \mathrm{~S}$ GenBank/strain \\
\hline \multirow{9}{*}{ T. stromaticum/H. stromatica } & & Z9592669: TR75 \\
\hline & & Z9592669: CBS 993.97 \\
\hline & AY937418*: G.J.S. 97-183 & AF09828788: G.J.S. 97-179 \\
\hline & AY937434*: G.J.S. 97-179 & AF09791388: G.J.S. 97-183 \\
\hline & AY937436*: G.J.S. 00-108 & AF09791088: G.J.S. 97-181 \\
\hline & AY937447*: G.J.S. 97-181 & AF09791288: G.J.S. 97-182 \\
\hline & & AF097911 ${ }^{88:}$ G.J.S. 97-180 \\
\hline & & AF09828764: CBS 101875 \\
\hline & & DQ083013*: G.J.S. 00-108 \\
\hline H. sulawesensis & AY737730*: G.J.S. 85-228 & AY737753*: G.J.S. 85-228 \\
\hline T. surrotundum/H. surrotunda & AY737734*: G.J.S. 88-73 & AY737769*: G.J.S. 88-73 \\
\hline T. tawa/H. tawa & AY737739*: G.J.S. 97-174 & AY737756*: G.J.S. 97-174 \\
\hline T. thailandicum/H. thailandica & AY737748*: G.J.S. 97-61 & AY737772*: G.J.S. 97-61 \\
\hline T. thelephoricola/H. thelephoricola & AY737735*: G.J.S. 95-135 & AY737776*: G.J.S. 95-135 \\
\hline T. tomentosum & AY750882*: DAOM 178713a & DQ085432*: DAOM 178713a \\
\hline \multirow[t]{3}{*}{ T. velutinum } & AY937415*: DAOM 230013 & AF149873'14: TUB F784 \\
\hline & AY937446*: DAOM 230014 & AF14987314: TUB F801 \\
\hline & & DQ083010*: DAOM 230014 \\
\hline \multirow{6}{*}{$\begin{array}{l}\text { T. virens } / H . \text { virens } \\
\text { including T. flavofuscum }\end{array}$} & AY750894*: G.J.S. 01-287 & DQ083023*: G.J.S. 01-287 \\
\hline & AY750891*: DAOM 167652 & AF09900664: Gli 3 \\
\hline & & AF09900764: Gli 20 \\
\hline & & AF099005 ${ }^{64}:$ AF222865, CBS 249.59 \\
\hline & & AF32855226: G.J.S. 95-194 \\
\hline & & AF09900864: Gli 21 \\
\hline H. virescentiflava & AY737749*: P.C. 278 & AY737768*: P.C. 278 \\
\hline \multirow[t]{9}{*}{ T. viride/H. rufa } & AY376052 $50:$ CBS 240.63 & AJ230678 $86:$ ATCC 28020 \\
\hline & AY37605350: CBS 101526 & X93986 $6^{86}:$ TR 8 \\
\hline & AY37605450: ATCC 28038 & X93978 $86:$ AF127150, ATCC 18652 \\
\hline & AY937413*: CBS 439.95 & AJ23067886: G.J.S. 91-62, BBA 770238, G.J.S. 92-14, \\
\hline & AY937449*: ATCC 28020 & G.J.S. $92-15$ \\
\hline & & X9398086: G.J.S. $89-127$ \\
\hline & & AY $376052^{50}:$ CBS 240.63 \\
\hline & & AY380908 50 : CBS 202526 \\
\hline & & AY38090950: ATCC 28038 \\
\hline
\end{tabular}


species have long been known to be soil fungi, and they are certainly common in all soils $(47,83,105-107)$. More recently, they have been found in water-damaged building materials or indoor dust (98) and in hospitals (29), and may adversely affect human health $(65,96)$. Trichoderma species have been involved in several cases of invasive infections of immunocompromised humans $(29,57,60)$ and in allergic reactions (52), the most common being $T$. longibrachiatum (29) and T. citrinoviride (60). T. longibrachiatum and T. citrinoviride are closely related members of Trichoderma sect. Longibrachiatum and are able to grow and sporulate well at $40^{\circ} \mathrm{C}(89)$, which may explain their dominance in clinical settings.

\section{Neighbor-Joining RPB2 + TEF}

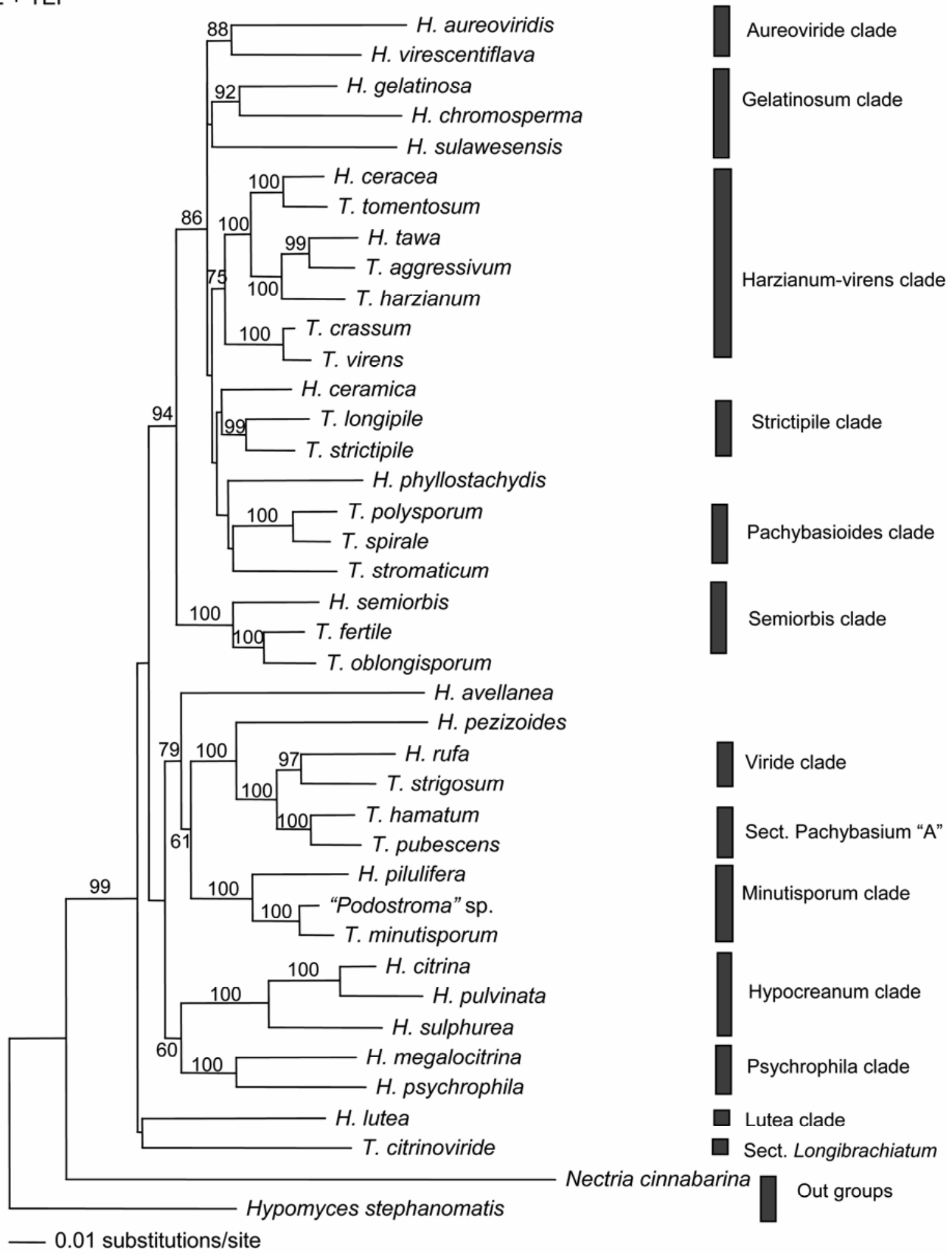

Fig. 1. Neighbor-joining tree with combined RPB2 and EF-1 $\alpha$ data sets. Numbers at branches represent bootstrap values based on 1,000 replicates. 
Trichoderma species are considered now to be opportunistic, avirulent plant symbionts (48). These fungi may invade the first few layers of the root hairs and stimulate resistance to attack by pathogens either locally, in the roots, or at a distance. The ability of some Trichoderma species to induce resistance to fungal parasites in crops considerably augments their arsenal, beyond mycoparasitism (28), antibiosis (51), and plant-growth stimulation in general (6).

Typically, Trichoderma species are thought of as being soil fungi, but Evans et al. (43) discovered many Trichoderma species and other soil fungi such as Clonostachys, Fusarium, and Cylindrocarpon as well as unidentified basidiomycetes existing as endophytes in healthy tree bolls and pods of the cacao relative Theobroma gileri. This contrasts to the endophytes of leaves of Theobroma cacao, and other tropical tree species, which are dominated by ascomycetous fungi that sporulate on above-ground parts of plants such as Xylariaceae, Colletotrichum, Botryosphaeria (3), and many others (see references in Evans et al. [43]). The only study that I know of that enumerates specifically stem endophytes of a tree is Evans et al. (43). On the basis of this one report, it is impossible to say that there is a general trend among plants for soil fungi to occur as endophytes in stems and for foliar/twig fungi to occur as endophytes in leaves, but the possibility is intriguing. The species of Trichoderma most commonly isolated from stems of Theobroma species is T. harzianum, which is also the most common species in the genus. Smaller numbers of named Trichoderma species, such as T. spirale have been found too, but several endophytic species remain to be described (G. J. Samuels, unpublished data).

Can endophytic fungi be utilized in biological control against plant disease? There is a wealth of literature affirming this possibility in grasses but little work has been done with other types of plants. A mixture of foliar endophytes introduced into mature leaves of cacao (Theobroma cacao) gave localized protection from infection by a Phytophthora species, but there was no evidence of systemic resistance to the pathogen (4). Bryan Bailey and Ron Collins (personal communication) have established endophytic colonization of shoots and leaves of tomato and cacao seedlings with the cosmopolitan soil species $T$. asperellum; early results suggest that those seedlings resist infection by the cacao pathogen Crinipellis perniciosa. It also has been possible to reintroduce Trichoderma stem endophytes into cacao seedlings (43,50; T. Gianfagna, personal communication). Two of them, both undescribed species, inhibit in vitro growth of the serious cacao pathogen, Moniliophthora roreri (the cause of frosty pod rot disease of cacao; K. Holmes, T. Gianfagna, and C. Suarez, personal communication); in vitro and in planta both produce nonanoic acid and 6-pentyl- $\alpha$-pyrone (M. Aneja and T. Gianfagna, personal communication), compounds known to inhibit germination of spores of plant-pathogenic fungi $(95,101)$. The production of these metabolites in plants must contribute to induced host resistance to disease. Two additional endophytic species, T. ovalisporum (50) and Trichoderma sp. nov. (G. J. Samuels, R. Bateman, K. Holmes, and C. Suarez, unpublished data), have demonstrated in vitro ability to parasitize the pseudostroma of $M$. roreri. The first field trials with $T$. ovalisporum indicate promise in protecting pods of Theobroma cacao from infection by $M$. roreri (K. Holmes and R. Bateman, personal communication).

Most species of Trichoderma are not specific as to substratum, although some Hypocrea species are, including H. latizonata on birds nest fungi, $H$. pulvinata on bracket fungi, and $H$. avellanea on Collybia subnuda. These Hypocrea species, however, do not produce typical Trichoderma anamorphs. T. stromaticum and its teleomorph, $H$. stromatica, mentioned above, are unusual in that they are found only in association with Theobroma species in tropical America. T. stromaticum was originally found on brooms on Theobroma cacao caused by Crinipellis perniciosa (88). Since then it has been isolated as an endophyte of Theobroma cacao (G. J. Samuels, unpublished data). No doubt additional hostspecific species will be found.

Some things to expect. The discovery of Trichoderma species as endophytes of cacao and cacao relatives suggests a potential for protecting crop plants against attack by pathogens through induced resistance, antibiosis, or both. In addition, endophytic fungi will be found to produce many novel, biochemically and medically important metabolites.

Many Trichoderma species are known under two names, viz. the name of the Trichoderma anamorph and that of the Hypocrea teleomorph (e.g., H. lixii, the teleomorph of T. harzianum; Table 1). That these two names represent a single life cycle, one organism, is obvious and one might question whether two names for one organism are necessary. With the use of molecular tools, it is possible to recognize the relationship between anamorphs and teleomorphs to combine morphologically disparate parts of a single life-cycle. Because Trichoderma with and without Hypocrea teleomorphs consistently cluster in a single, well-supported clade, there is no doubt that they are the same genus (25). There is a movement in the taxonomic mycology community to adopt "one fungus/one name", but the mechanism for achieving that goal is not clear. Under the current International Code of Botanical Nomenclature (Art. 59), the correct name for the whole organism (the "holomorph" under any single-name scheme) would be Hypocrea, the name of the sexual stage. One way would be to modify or delete Art. 59, so as to enable the names of anamorph and teleomorph to compete on priority (date of publication). Under this scenario, Trichoderma (1794) is older than Hypocrea (1825) and would thus be the accepted name of the holomorph regardless of whether a sexual stage was produced or not. In 6 years, when the next botanical congress will take place and changes to the International Code of Botanical Nomenclature will be considered, it is likely that moves toward one fungus/one name will be made.

Over the past 35 years, the number of named Trichoderma species has increased from nine aggregate species to about 80 phylogenetic species. Trichoderma is now in a discovery phase; as new niches and new geographical regions are explored, many new species of Trichoderma will be discovered (58). The development of molecular tools has enabled the positive identification of any strain and the development of a phylogenetic tree. We are now able to account taxonomically for a significant component of the biological diversity of soil, predict biological activity, and communicate results through the use of accurately determined names. Identification of Trichoderma species, and most likely species in other economically important and species-rich genera, will rely on DNA sequence data as the limits of phenotype to distinguish species are reached.

Many activities of humankind interface with Trichoderma. The genus is widely regarded as completely benign, but the negative aspects of some members of this genus in human and animal health are significant and should not be overlooked-as is the case with any mold. For example, one should consider seriously whether it is safe to use T. longibrachiatum in biological control because this species can grow and sporulate at human body temperature and thus may pose a risk to individuals who apply it. However, most species and activities of Trichoderma species are beneficial for the enzymes that they produce, for their plant growth promoting activities, and in biological control of plant diseases. Trichoderma species represent a major component of the diversity of Life on Earth. The numbers, diversity, roles, and interactions of Trichoderma species in the environment are only now being revealed. Many new species will be found, and processes will be unraveled for well-known and those yet-to-be-discovered members of this fascinating genus of molds. 


\section{ACKNOWLEDGMENTS}

A. Ismaiel, USDA-ARS, Systematic Botany and Mycology Laboratory, Beltsville, MD, provided the new DNA sequences reported in Table 1. P. Chaverri, Howard University, Washington D.C., prepared Figure 1.

\section{LITERATURE CITED}

1. Abbott, E. V. 1926. Taxonomic studies on soil fungi. Iowa State Coll. J. Sci. 1:15-36.

2. Aime, M. C., and Phillips-Mora, W. The causal agents of witches' broom and frosty pod rot of cocoa (Theobroma cacao) form a new lineage of Marasmiaceae. Mycologia (In press).

3. Arnold, A. E., and Herre, E. A. 2003. Canopy cover and leaf age affect colonization by tropical fungal endophytes: Ecological pattern and process in Theobroma cacao (Malvaceae). Mycologia 95:388-398.

4. Arnold, A. E., Mejia, L. C., Kyllo, D., Rojas, E. I., Maynard, Z., Robbins, N., and Herre, E. A. 2003. Fungal endophytes limit pathogen damage in a tropical tree. Proc. Natl. Acad. Sci. USA 100:1564915654.

5. Arx, J. A. von. 1987. Plant pathogenic fungi. Nova Hedwigia Beih. 87:1288.

6. Bailey, B. A., and Lumsden, R. D. 1998. Direct effects of Trichoderma and Gliocladium on plant growth and resistance to pathogens. Pages 185204 in: Trichoderma and Gliocladium. Vol. 2. G. E. Harman and C. P. Kubicek, eds. Taylor \& Francis, London.

7. Bezerra, J. L., Costa, J. C., Bastos, C. N., and Faleiro, F. G. 2003. Hypocrea stromatica sp. nov. teleomorfo de Trichoderma stromaticum. Fitopatol. Bras. 28:408-412.

8. Bisby, G. R. 1939. Trichoderma viride Pers. ex Fries, and notes on Hypocrea. Trans. Br. Mycol. Soc. 23:149-168.

9. Bissett, J. 1984. A revision of the genus Trichoderma. I. Section Longibrachiatum sect. nov. Can. J. Bot. 62:924-931.

10. Bissett, J. 1991. A revision of the genus Trichoderma. II. Intrageneric classification. Can. J. Bot. 60:2357-2372.

11. Bissett, J. 1991. A revision of the genus Trichoderma. III. Section Pachybasium. Can. J. Bot. 69:2373-2417.

12. Bissett, J. 1991. A revision of the genus Trichoderma. IV. Additional notes on section Longibrachiatum. Can. J. Bot. 69:2418-2420.

13. Bissett, J. 1992. Trichoderma atroviride. Can. J. Bot. 70:639-641.

14. Bissett, J., Szakacs, G., Nolan, C. A., Druzhinina, I., Gradinger, C., and Kubicek, C. P. 2003. New species of Trichoderma from Asia. Can. J. Bot. 81:570-586.

15. Brian, P. W., Curtis, P. J., Hemming, H. G., and McGowan, J. C. 1946. The production of viridin by pigment-forming strains of Trichoderma viride. Ann. Appl. Biol. 33:190-200.

16. Brian, P. W., and Hemming, H. G. 1945. Gliotoxin, a fungistatic metabolic product of Trichoderma viride. Ann. Appl. Biol. 32:214-220.

17. Brian, P. W., and McGowan, J. C. 1945. Viridin: A highly fungistatic substance produced by Trichoderma viride. Nature (London) 156:144.

18. Canham, S. C. 1969. Taxonomy and morphology of Hypocrea citrina. Mycologia 56:315-331.

19. Carbone, I., and Kohn, L. M. 1999. A method for designing primer sets for speciation studies in filamentous ascomycetes. Mycologia 91:553556.

20. Carey, S. T., and Rogerson, C. T. 1976. Taxonomy and morphology of a new species of Hypocrea on Marasmius. Brittonia 28:381-389.

21. Chaverri, P., Candoussau, F., and Samuels, G. J. 2004. Hypocrea phyllostachydis and its Trichoderma anamorph, a new bambusicolous species from France. Mycol. Prog. 3:19-28.

22. Chaverri, P., Castlebury, L. A., Overton, B. E., and Samuels, G. J. 2004. Hypocrea/Trichoderma: Species with conidiophore elongations and green conidia. Mycologia 95:1100-1140.

23. Chaverri, P., Castlebury, L. A., Samuels, G. J., and Geiser, D. M. 2003. Multilocus phylogenetic structure of Trichoderma harzianum/Hypocrea lixii complex. Mol. Phylogenet. Evol. 27:302-313.

24. Chaverri, P., and Samuels, G. J. 2002. Hypocrea lixii, the teleomorph of Trichoderma harzianum. Mycol. Prog. 1:283-286.

25. Chaverri, P., and Samuels, G. J. 2004. Hypocrea/Trichoderma (Ascomycota, Hypocreales, Hypocreaceae): Species with green ascospores. Stud. Mycol. 48:1-116.

26. Chaverri, P., Samuels, G. J., and Stewart, E. L. 2001. Hypocrea virens sp. nov., the teleomorph of Trichoderma virens. Mycologia 93:11131124.

27. Chaverri, P., Samuels, G. J., Stewart, E. L., and Umaña, L. 2001. Hypocrea nigrovirens, a new species with a gliocladium-like anamorph. Mycologia 93:758-763.
28. Chet, I., Benhamou, N., and Haran, S. 1998. Mycoparasitism and lytic enzymes. Pages 153-172 in: Trichoderma and Gliocladium. Vol. 2. G. E. Harman and C. P. Kubicek, eds. Taylor \& Francis, London.

29. Chouaki, T., Lavarde, V., Lachaud, L., Raccurt, C. P., and Hennequin, C. 2002. Invasive infections due to Trichoderma species: Report of 2 cases, findings of in vitro susceptibility testing, and review of the literature. Clinic. Infect. Dis. 35:1360-1367.

30. Cooney, J. M., Vanneste, D. R., Lauren, D. R., and Hill, R. A. 1997. Quantitative determination of the antifungal compound 6-pentyl-alphapyrone (6PAP) using a simple plate bioassay. Lett. Appl. Microbiol. 24:47-50.

31. Dingley, J. M. 1957. Life history studies in the genus Hypocrea Fr. Trans. Proc. R. Soc. New Zealand 84:689-693.

32. Dodd, S., Lieckfeldt, E., and Samuels, G. J. 2003. Hypocrea atroviridis sp. nov.: The teleomorph of Trichoderma atroviride. Mycologia 95: $27-40$.

33. Dodd, S. L., Lieckfeldt, E., Chaverri, P., Overton, B. E., and Samuels, G. J. 2002. Taxonomy and phylogenetic relationships of two species of Hypocrea with Trichoderma anamorphs. Mycol. Prog. 1:409-428.

34. Doi, Y. 1969. Revision of the Hypocreales with cultural observations IV. The genus Hypocrea and its allies in Japan (1) General part. Bull. Natl. Sci. Mus. 12:693-724.

35. Doi, Y. 1971. Some species of the genus Hypocrea. Bull. Natl. Sci. Mus. 14:387-400.

36. Doi, Y. 1972. Revision of the Hypocreales with cultural observations IV. The genus Hypocrea and its allies in Japan (2) Enumeration of the species. Bull. Natl. Sci. Mus. 15:649-751.

37. Doi, Y. 1974. Hypocrea rufa (Pers. ex Fr.) Fr., Hypomyces aurantius (Pers. per S.F. Gray) Tul., and their allies in Japan. Jpn. J. Bot. 20:403412.

38. Doi, Y. 1975. Revision of the Hypocreales with cultural observations VII. The genus Hypocrea and its allied genera in South America (1). Bull. Natl. Sci. Mus. Ser. B (Bot.) 1:1-33.

39. Doi, Y. 1976. Revision of the Hypocreales with cultural observations IX. The genus Hypocrea and its allied genera in South America (2). Bull. Natl. Sci. Mus. Ser. B (Bot.) 2:119-131.

40. Doi, Y., Abe, Y., and Sugiyama, J. 1987. Trichoderma Sect. Saturnisporum, sect. nov. and Trichoderma ghanense, sp. nov. Bull. Natl. Sci. Mus. Ser. B (Bot.) 13:1-9.

41. Druzhinina, I., and Kopchinskiy, A. 2004. TrichoBLAST version 1.0. Multiloci database of phylogenetic markers and similarity search. Published online by the International Subcommission on Trichoderma and Hypocrea (ISTH). http://www.isth.info/tools/blast/index.php.

42. Druzhinina, I., and Kopchinskiy, A. 2004. TrichOKEY version 1.0. Trichoderma oligonucleotide key. Published online by the International Subcommission on Trichoderma and Hypocrea (ISTH). http://www.isth.info/ tools/molkey/index.php.

43. Evans, H. C., Holmes, K. A., and Thomas, S. E. 2003. Endophytes and mycoparasites associated with an indigenous forest tree, Theobroma gileri, in Ecuador and a preliminary assessment of their potential as biocontrol agents of cocoa diseases. Mycol. Prog. 2:149-160.

44. Gams, W., and Bissett, J. 1998. Morphology and identification of Trichoderma. Pages 1-34 in: Trichoderma and Gliocladium. Vol. 1. C. P. Kubicek and G. E. Harman, eds. Taylor \& Francis, London.

45. Ghisalberti, E. L., and Sivasithamparam, K. 1991. Antifungal antibiotics produced by Trichoderma spp. Soil Biol. Biochem. 23:1011-1020.

46. Grondona, I., Hermosa, M. R., Tejada, M., Gomis, M. D., Mateos, P. F., Bridge, P. F., Monte, E., and García-Acha, I. 1997. Physiological and biochemical characterization of Trichoderma harzianum, a biological control agent against soilborne fungal plant pathogens. Appl. Environ. Microbiol. 63:3189-3198.

47. Hagn, A., Pritsch, K., Schloter, M., and Munch, J. C. 2003. Fungal diversity in agricultural soil under different farming management systems, with special reference to biocontrol strains of Trichoderma spp. Biol. Fert. Soils 38:236-244.

48. Harman, G. E., Howell, C. R., Viterbo, A., Chet, I., and Lorito, M. 2004. Trichoderma species-opportunistic, avirulent pant symbionts. Nat. Rev. Microbiol. 2:43-56.

49. Hermosa, M. R., Grondona, I., Diaz-Minguez, J. M., Iturriaga, E. A., and Monte, E. 2001. Development of a strain-specific SCAR marker for the detection of Trichoderma atroviride 11, a biological control agent against soilborne fungal plant pathogens. Curr. Genet. 38: 343-350.

50. Holmes, K. A., Schroers, H.-J., Thomas, S. E., Evans, H. C., and Samuels, G. J. 2004. Taxonomy and biocontrol potential of a new species of Trichoderma from the Amazon basin of South America. Mycol. Prog. 3:199210.

51. Howell, C. R. 1998. The role of antibiosis in biocontrol. Pages 173-184 in: Trichoderma and Gliocladium. Vol. 2. G. E. Harman and C. P. Kubicek, eds. Taylor \& Francis, London. 
52. Jaakkola, M. S., Latitinen, S., Piipari, R., Uitti, J., Nordman, H., Haapala, A. M., and Jaakkola, J. J. 2002. Immunoglobulin G antibodies against indoor dampness-related microbes and adult-onset asthma: A population-based incident case-control study. Clinic. Exp. Immunol. 129:107-112.

53. Jaklitsch, W. M., Komon, M., Kubicek, C. P., and Druzhinina, I. Hypocrea voglmayrii sp. nov. from the Austrian Alps represents a new phylogenetic clade in Hypocrea/Trichoderma. Mycologia (In Press).

54. Kalyani, A., Prapulla, S. G., and Karanth, N. G. 2000. Study on the production of 6-pentyl-alpha-pyrone using two methods of fermentation. Appl. Microbiol. Biotechnol. 53:610-612.

55. Kindermann, J., El-Ayouti, Y., Samuels, G. J., and Kubicek, C. P. 1998. Phylogeny of the genus Trichoderma based on sequence analysis of the internal transcribed spacer region 1 of the rDNA cluster. Fungal Genet. Biol. 24:298-309.

56. Klein, D., and Eveleigh, D. E. 1998. Ecology of Trichoderma. Pages 5774 in: Trichoderma and Gliocladium. Vol. 1. C. P. Kubicek and G. E. Harman, eds. Taylor \& Francis, London.

57. Kredics, L., Antal, Z., Doczi, I., Manczinger, L., Kevei, F., and Nagy, E. 2003. Clinical importance of the genus Trichoderma - a review. Acta Microbiol. Immunol. Hungarica 50:105-117.

58. Kubicek, C. P., Bissett, J., Druzhinina, I., Kullnig-Gradinger, C. M., and Szakacs, G. 2003. Genetic and metabolic diversity of Trichoderma: A case study on South-East Asian isolates. Fungal Genet. Biol. 38:310-319.

59. Kubicek, C. P., Bolzlbauer, U. M., Kovacs, W., Mach, R. L., Kuhls, K., Lieckfeldt, E., Borner, T., and Samuels, G. J. 1996. Cellulase formation by species of Trichoderma sect. Longibrachiatum and of Hypocrea spp. with anamorphs referable to Trichoderma sect. Longibrachiatum. Fungal Genet. Biol. 20:105-114

60. Kuhls, K., Lieckfeldt, E., Börner, T., and Guého, E. 1999. Molecular reidentification of human pathogenic Trichoderma isolates as Trichoderma longibrachiatum and Trichoderma citrinoviride. Med. Mycol. 37:25-33

61. Kuhls, K., Lieckfeldt, E., Samuels, G. J., Börner, T., Meyer, W., and Kubicek, C. P. 1997. Revision of Trichoderma sect. Longibrachiatum including related teleomorphs based on analysis of ribosomal DNA internal transcribed spacer sequences. Mycologia 89:442460.

62. Kuhls, K., Lieckfeldt, E., Samuels, G. J., Kovacs, W., Meyer, W., Petrini, O., Gams, W., Börner, T., and Kubicek, C. P. 1996. Molecular evidence that the asexual industrial fungus Trichoderma reese $i$ is a clonal derivative of the ascomycete Hypocrea jecorina. Proc. Natl. Acad. Sci. USA 93:7755-7760.

63. Kullnig, C. M., Krupica, T., Woo, S. L., Mach, R. L., Rey, M., Lorito, M., and Kubicek, C. P. 2001. Confusion abounds over identities of Trichoderma biocontrol isolates. Mycol. Res. 105:770-771.

64. Kullnig-Gradinger, C. M., Szakacs, G., and Kubicek, C. P. 2002. Phylogeny and evolution of the genus Trichoderma: A multigene approach. Mycol. Res. 106:757-767.

65. Larsen, F. O., Meyer, H. W., Ebbehoj, N., Gyntelberg, F., Sherson, D., Netterstrom, B., Gravesen, S., and Norn, S. 1997. Are fungi-specific IgE found in staff suffering from nonallergic sick building syndrome? Inflamm. Res. 46(Suppl. 1):S79-S80.

66. Lieckfeldt, E., Kuhls, K., and Muthumeenakshi, M. 1998. Molecular taxonomy of Trichoderma and Gliocladium and their teleomorphs. Pages 35-56 in: Trichoderma and Gliocladium. Vol. 1. C. P. Kubicek and G. E. Harman, eds. Taylor \& Francis, London.

67. Lieckfeldt, E., Kullnig, C., Samuels, G. J., and Kubicek, C. P. 2000. Sexually competent, sucrose- and nitrate-assimilating strains of Hypocrea jecorina (Trichoderma reesei) from South American soils. Mycologia 92:374-480.

68. Lieckfeldt, E., Kullnig, M., Kubicek, C. P., Samuels, G. J., and Börner, T. 2001. Trichoderma aureoviride: Phylogenetic position and characterization. Mycol. Res. 105:313-322.

69. Lieckfeldt, E., Samuels, G. J., Börner, T., and Gams, W. 1998. Trichoderma koningii: Neotypification and Hypocrea teleomorph. Can. J. Bot. 76:1507-1522.

70. Lieckfeldt, E., Samuels, G. J., and Nirenberg, H. I. 1999. A morphological and molecular perspective of Trichoderma viride: Is it one or two species? Appl. Environ. Microbiol. 65:2418-2428.

71. Lu, B. S., Druzhinina, I. S., Fallah, P., Chaverri, P., Gradinger, C., Kubicek, C. P., and Samuels, G. J. 2004. Hypocrea/Trichoderma species with pachybasium-like conidiophores: Teleomorphs for T. minutisporum and T. polysporum and their newly discovered relatives. Mycologia 96:310-342.

72. Lutzoni, F., Kauff, F., Cox, S. J., McLaughlin, D., Celio, G., et al. 2004. Assembling the fungal tree of life: Progress, classification, and evolution of subcellular traits. Am. J. Bot. 91:1466-1480.

73. Mathieson, M. J. 1952. Ascospore dimorphism and mating type in
Chromocrea spinulosa (Fuckel) Petch n. comb. Ann. Bot. N.S. 16: $449-468$

74. Nielsen, K. F., Gräfenhan, T., Zafari, D., and Thrane, U. 2005. Trichothecene production by Trichoderma brevicompactum. J. Agric. Food Chem. 53:8190-8196.

75. Overton, B. E., Stewart, E. L., Geiser, D. M., Wenner, N. G., and Jaklitsch, W. Systematics of Hypocrea citrina and allies. Stud. Mycol. (In Press).

76. Perkins, D. 1987. Mating-type switching in filamentous ascomycetes. Genetics 115:215-216.

77. Persoon, C. H. 1794. Disposita methodica fungorum. Römer's Neues Mag. Bot. 1:81-128.

78. Rehner, S. A., and Samuels, G. J. 1994. Taxonomy and phylogeny of Gliocladium analyzed by large subunit rDNA sequences. Mycol. Res. 98:625-634.

79. Rehner, S. A., and Samuels, G. J. 1995. Molecular systematics of the Hypocreales: A teleomorph gene phylogeny and the status of their anamorphs. Can. J. Bot. 73(Suppl. 1):S816-S823.

80. Rifai, M. A. 1969. A revision of the genus Trichoderma. Mycol. Pap. 116:1-56.

81. Rifai, M. A., and Webster, J. 1966. Culture studies of Hypocrea and Trichoderma II. H. aureo-viridis and $H$. rufa f. sterilis f. nov. Trans. Br. Mycol. Soc. 49:296.

82. Rifai, M. A., and Webster, J. 1966. Culture studies on Hypocrea and Trichoderma III. $H$. lactea $(=H$. citrina $)$ and $H$. pulvinata. Trans. $\mathrm{Br}$. Mycol. Soc. 49:297-310.

83. Roiger, D. J., Jeffers, S. N., and Caldwell, R. W. 1991. Occurrence of Trichoderma species in apple orchard and woodland soils. Soil Biol. Biochem. 23:353-359.

84. Samuels, G. J., Chaverri, P., Farr, D. F., and McCray, E. B. Trichoderma Online. Systematic Botany \& Mycology Laboratory, ARS, USDA. Retrieved August 31, 2004, from http://nt.ars-grin.gov/taxadescriptions/ keys/TrichodermaIndex.cfm

85. Samuels, G. J., Dodd, S. L., Gams, W., Castlebury, L. A., and Petrini, O. 2002. Trichoderma species associated with the green mold epidemic of commercially grown Agaricus bisporus. Mycologia 94:146170.

86. Samuels, G. J., Lieckfeldt, E., and Nirenberg, H. I. 1999. Trichoderma asperellum, a new species with warted conidia, and redescription $T$. viride. Sydowia 51:71-88.

87. Samuels, G. J., and Lodge, D. J. 1996. Three species of Hypocrea with stipitate stromata and Trichoderma anamorphs. Mycologia 88:302315 .

88. Samuels, G. J., Pardo-Schultheiss, R., Hebbar, P., Lumsden, R. D., Bastos, C. N., Costa, J. C., and Bezerra, J. L. 2000. Trichoderma stromaticum, sp. nov., a parasite of the cacao witches broom pathogen. Mycol. Res. 104:760-764.

89. Samuels, G. J., Petrini, O., Kuhls, K., Lieckfeldt, E., and Kubicek, C. P. 1998. The Hypocrea schweinitzii complex and Trichoderma sect. Longibrachiatum. Stud. Mycol. 41:1-54.

90. Samuels, G. J., and Seifert, K. A. 1995. The impact of molecular characters on systematics of filamentous ascomycetes. Annu. Rev. Phytopathol. 33:37-67.

91. Sanogo, S., Pomella, A., Hebbar, P. K., Bailey, B., Costa, J. C. B., Samuels, G. J., and Lumsden, R. D. 2002. Production and germination of conidia of Trichoderma stromaticum, a mycoparasite of Crinipellis perniciosa on cacao. Phytopathology 92:1032-1037.

92. Seifert, K. A. 1985. A monograph of Stilbella and some allied Hyphomycetes. Stud. Mycol. 27:1-235.

93. Seifert, K. A., and Samuels, G. J. 1997. Two new hypocrealean fungi with synnematous anamorphs. Mycologia 89:512-520.

94. Sivasithamparam, K., and Ghisalberti, E. L. 1998. Secondary metabolism in Trichoderma and Gliocladium. Pages 139-191 in: Trichoderma and Gliocladium. Vol. 1. C. P. Kubicek and G. E. Harman, eds. Taylor \& Francis, London

95. Smith, R. J., and Grula, E. A. 1982. Toxic components on the larval surface of the corn earworm (Heliothis zea) and their effects on germination and growth of Beauveria bassiana. J. Invertebr. Pathol. 39:15-22.

96. Tang, P., Mohan, S., Sigler, L., Witterick, I., Summerbell, R., Campbell, I., and Mazzulli, T. 2003. Allergic fungal sinusitis associated with Trichoderma longibrachiatum. J. Clinic. Microbiol. 41:5333-5336.

97. Taylor, J. W., Jacobson, D. J., Kroken, S., Kasuga, T., Geiser, D. M., Hibbett, D. S., and Fisher, M. C. 2004. Phylogenetic species recognition and species concepts in fungi. Fungal Genet. Biol. 31:21-32.

98. Thrane, U., Poulsen, S. B., Nirenberg, H. I., and Lieckfeldt, E. 2001. Identification of Trichoderma strains by image analysis of HPLC chromatograms. FEMS Microbiol. Lett. 203:249-255.

99. Tulasne, L.-R., and Tulasne, C. 1865. Selecta fungorum carpologia. Jussu, Paris. 
100. Turner, D., Kovacs, W., Kuhls, K., Lieckfeldt, E., Peter, B., Arisan-Atac, I., Strauss, J., Samuels, G. J., Börner, T., and Kubicek, C. P. 1997. Biogeography and phenotypic variation in Trichoderma sect. Longibrachiatum and associated Hypocrea species. Mycol. Res. 101:449-459.

101. Wainwright, M. 1982. Origin of fungal colonies on dilution and soil plates determined using nonanoic acid. Trans. Br. Mycol. Soc. 79:178-179.

102. Webster, J. 1964. Culture studies on Hypocrea and Trichoderma I. Comparison of perfect and imperfect states of $H$. gelatinosa, $H$. rufa and Hypocrea sp. 1. Trans. Br. Mycol. Soc. 47:75-96.

103. Webster, J., and Rifai, M. A. 1968. Culture studies on Hypocrea and Trichoderma IV. Hypocrea pilulifera sp. nov. Trans. Br. Mycol. Soc. 51:511-514
104. Wheeler, Q., and Blackwell, M. 1984. Cladistics and the historical component of fungus-insect relationships. Pages 5-41 in: Fungus-Insect Relationships. Perspectives in Ecology and Evolution. Q. Wheeler and M. Blackwell, eds. Columbia University Press, New York.

105. Widden, P. 1979. Fungal populations from forest soils in southern Quebec. Can. J. Bot. 57:1324-1331.

106. Widden, P., and Abitol, J. 1980. Seasonality of Trichoderma species in a spruce-forest soil. Mycologia 72:775-784

107. Wuczowsky, M., Druzhinina, I., Gherbawy, Y., Klug, B., Prillinger, H., and Kubicek, C. P. 2003. Species pattern and genetic diversity of Trichoderma in a mid-European, primeval floodplain-forest. Microbiol. Res. 158:125-133.

\section{Errata}

Corrections to the following errors or deletions were made to this manuscript on March 16, 2006. On page 196, the type of Pachybasium is T. hamatum. On page 201, it is Trichoderma pseudokoningii that has an Australasian distribution, not T. koningii; T. koningii, a species reported to have a wide geographic distribution actually has a limited, north temperate distribution. On page 201, the incomplete sentence has been corrected as follows: "T. reesei, the species best known for the commercial production of cellulase enzymes, was until recently known only from a single culture isolated from canvas material in the Solomon Islands of the Pacific region. We now know that this is the anamorph of $H$. jecorina (62), a species that is limited in its distribution to a narrow Equatorial band, and we have isolated it directly from natural substrata in Brazil and French Guiana (67)." On page 203, the genus Trichoderma was first published by Persoon in 1794. 